\title{
Cationic Dyes Immobilized on Cellulose Acetate Surface Modified with Titanium Dioxide: Factorial Design and an Application as Sensor for NADH
}

\author{
Andrea A. Hoffmann, ${ }^{a}$ Silvio L. P. Dias, ${ }^{* a}{ }^{2}$ Edilson V. Benvenutti, ${ }^{a}$ Eder C. Lima, ${ }^{a}$ Flávio A. Pavan, ${ }^{a}$ \\ Jordana R. Rodrigues, ${ }^{a}$ Rodrigo Scotti, ${ }^{a}$ Emerson S. Ribeiro ${ }^{b}$ and Yoshitaka Gushikem ${ }^{c}$
}

\author{
${ }^{a}$ Instituto de Química, Universidade Federal do Rio Grande do Sul, Av. Bento Gonçalves 9500, \\ CP 15003, 91501-970 Porto Alegre-RS, Brazil \\ ${ }^{b}$ Instituto de Química, Universidade Federal do Rio de Janeiro, \\ 21941-909 Rio de Janeiro-RJ, Brazil \\ ${ }^{c}$ Instituto de Química, Universidade Estadual de Campinas, \\ 13083-970 Campinas-SP, Brazil
}

\begin{abstract}
As propriedades eletroquímicas dos corantes catiônicos, azul de meldola e azul de toluidina, imobilizados na superfície do acetato de celulose modificado com dióxido de titânio foram investigadas por voltametria cíclica. Os materiais sintetizados foram empregados como eletrodos de pasta de carbono. As propriedades mediadoras redox dos eletrodos modificados quimicamente com azul de meldola e azul de toluidina foram otimizadas utilizando um planejamento fatorial consistindo de dois níveis e quatro fatores com dois pseudo-pontos centrais ( $\mathrm{n}=20$ experimentos). A análise fatorial foi realizada para investigar as melhores condições de reversibilidade do processo redox tais como uma diminuição na separação entre os picos de potenciais anódico e catódico e razão de corrente próxima da unidade. Os fatores que apresentaram efeitos significantes na otimização global do sistema e que permitiram alcançar as melhores condições de reversibilidade de transferência de elétrons foram os fatores principais velocidade de varredura e tipo de eletrodo (azul de meldola ou azul de toluidina) além dos fatores de interação concentração do $\mathrm{KCl} \times$ tipo de eletrodo $(\mathrm{B} \times \mathrm{D})$ e a interação $\mathrm{pH} \times[\mathrm{KCl}] \times$ velocidade de varredura $(\mathrm{A} \times \mathrm{B} \times \mathrm{C})$. As melhores condições de reversibilidade eletroquímica obtidas foram: o eletrodo $\mathrm{CA}-\mathrm{TiO}_{2}-\mathrm{MB}, \mathrm{KCl} 1,0 \mathrm{~mol} \mathrm{~L}^{-1}$ como eletrólito suporte e velocidade de varredura de $10,0 \mathrm{mV} \mathrm{s}^{-1}$. Adicionalmente, o eletrodo modificado $\mathrm{CA}-\mathrm{TiO}_{2}-\mathrm{MB}$ foi testado como sensor amperométrico para a determinação de NADH com um limite de detecção de $0,1 \mu \mathrm{mol} \mathrm{L} \mathrm{L}^{-1}$.
\end{abstract}

The electrochemical properties of meldola blue and toluidine blue cationic dyes immobilized on cellulose acetate surface modified with titanium dioxide were investigated by cyclic voltammetry. The materials synthesized were employed as carbon paste electrodes. The redox mediator properties of the meldola blue and toluidine blue chemically modified electrodes were optimized using a factorial design, consisting of two levels and four factors with two pseudo-central points $(\mathrm{n}=20$ experiments). The factorial analysis was carried out by searching for better reversibility of the redox process, such as the lowest separation between anodic and cathodic potential peaks and a current ratio near unity. The factors that presented significant effects on the overall optimization of the system to achieve the best conditions of the reversibility of electron transfer were the main factors scan rate and type of electrode (meldola blue or toluidine blue), besides the interaction factors $\mathrm{KCl}$ concentration $\times$ type of electrode $(\mathrm{B} \times \mathrm{D})$ and the $\mathrm{pH} \times[\mathrm{KCl}]$ concentration $\times$ scan rate $(\mathrm{A} \times \mathrm{B} \times \mathrm{C})$ interaction. The best electrochemical reversibility conditions obtained were: using the $\mathrm{CA}_{-}-\mathrm{TiO}_{2}-\mathrm{MB}$ electrode, $1.0 \mathrm{~mol} \mathrm{~L}^{-1} \mathrm{KCl}$ as supporting electrolyte, at scan rate of $10.0 \mathrm{mV} \mathrm{s}^{-1}$. Afterwards, the $\mathrm{CA}-\mathrm{TiO}_{2}-\mathrm{MB}$ modified electrode was tested as an amperometric sensor for the determination of $\mathrm{NADH}$, with a detection limit of $0.1 \mu \mathrm{mol} \mathrm{L}-1$.

Keywords: meldola blue, toluidine blue, modified cellulose acetate, factorial design, carbon paste electrode, $\mathrm{NaDH}$

*e-mail: silvio@iq.ufrgs.br 


\section{Introduction}

The development of sensors that allow the measurement of some analytes that present analytical or environmental interest are of great importance to the scientific community. The electrochemical sensors or biosensors have awakened the scientific community attention, because these devices associated with the selectivity of the electrochemical measurements, attained with the use of electrochemical mediator species, have permitted the measurements of important analytes in different areas such as in medicine, pharmacy, manufactured feed and other areas. ${ }^{1}$

In this context, efforts have been made to develop new sensors presenting the electrochemical mediator species strongly immobilized at the surface of the sensor material in order to avoid their leaching under the operational conditions. ${ }^{1}$ The most common materials that are usually employed as an inert support for the preparation of chemically modified electrodes (CME) are silica gel, silica prepared by the sol-gel process and zeolites. ${ }^{2-4}$

Recently, the use of available alternative materials as cellulose and its derivatives as supports for preparation of electrochemical sensors has been increased. ${ }^{5}$ The Cellulose acetate is a cellulose ester firstly synthesized in 1865 by P. Schutzenberger that has been widely marketed during the last two decades for their thermoplastic properties. ${ }^{6}$ In particular, cellulose acetate is useful in preparing hybrid materials since it shows intrinsic advantages like low cost, high availability, good biodegradability and easy handling. ${ }^{5}$ In recent years, works on preparation of cellulose acetate-metal oxide hybrid materials has been carriedout by mixing the polymer and metal alkoxide solutions, followed by a phase inversion process. ${ }^{7-10}$ Since these oxides behave as good Lewis acids, immobilized reactants on the oxide-coated cellulose acetate have been used to prepare semi-permeable membranes, ${ }^{8,9}$ for enzyme immobilization ${ }^{11}$ and for preparation of electrochemical sensors. ${ }^{10,12}$

Metallic oxides such as titanium oxide $\left(\mathrm{TiO}_{2}\right)$ are very known due to their high ion exchange capacity and conductivity properties. ${ }^{13,14}$ Such characteristics are very attractive for using this metallic oxide for preparing hybrid material with cellulose, as a substrate for immobilization of electrochemical mediators. The conductivity property of $\mathrm{TiO}_{2}$ is able to mediate the electron transfer in CME. In spite of these advantages of using cellulose acetatemetal oxide hybrid materials as CME there are few applications of these electrochemical sensors reported in the literature. ${ }^{10,12}$
The electrooxidation of the reduced nicotinamide coenzymes (NADH and NADPH) have been a subject of great interest in recent years. ${ }^{15}$ This is due to approximately 300 known enzymes which require nicotinamide coenzymes as co-reactants in the bioprocess. ${ }^{15}$ The development of sensors for electrooxidation of NADH has been reported utilizing different electron mediators, ${ }^{16}$ which were immobilized (adsorbed or chemically bound) at the electrode surface, such as catechols, ${ }^{17}$ hydroquinones, ${ }^{18}$ diaminobenzenes, ${ }^{19}$ phenazines, ${ }^{20}$ phenoxazines $^{21}$ or phenothiazines, ${ }^{22}$ metal complexes. ${ }^{23}$ These mediators were frequently studied and used to cause substantial decrease in the overvoltage and also to accelerate the oxidation reaction of $\mathrm{NADH}$ at the electrode surface.

Phenoxazines and phenothiazines are dyes compounds that have been often considered as the most suitable species for producing chemically modified electrodes due to their operational stability of the immobilized mediator, and fast redox reaction between immobilized mediators at the sensor surface and NADH containing solutions. ${ }^{24}$ The redox behavior and efficient electrocatalytic properties of these organic dyes have been employed for the determination of different substrates such as $\mathrm{H}_{2} \mathrm{O}_{2}{ }^{25,26}$ alcohols, ${ }^{27}$ lactate, ${ }^{28-30}$ ammonia, ${ }^{31}$ acid formic ${ }^{32}$ and enzymes like aspartate aminotransferase ${ }^{33}$ and horseradish peroxidase. $^{26}$

The optimization of the experimental conditions that leads to the best values of the reversibility of an electrochemical system requires the study of several variables, such as kind of electrode, $\mathrm{pH}$ of the solution, concentration of supporting electrolyte, scan rate, etc. Conventionally, one performs the optimization in a univariate mode, where each independent variable is studied one at a time and the other variables are kept constant. After optimizing the variable, it is fixed at the best found value and the next variable will be explored in turn. Alternatively, all the variables could be studied employing statistical design of experiments. ${ }^{34,35}$ One of the simplest statistical designs is the factorial design $2^{\mathrm{k}}$. The factorial design determines which factors have important effects on a response as well as how the effect of one factor varies with the level of the other factors. ${ }^{34,35}$ The determination of factor interactions could only be attained using statistical designs of experiments, since it cannot be observed when the system optimization is carried out by varying just one factor at a time and fixing the others. ${ }^{34-40}$ This statistical design is used to examine the relationship between one or more response variables and a set of quantitative experimental factors. After that, it is necessary to find the factor settings that optimize the 
response. Although statistical design of experiments has largely been employed in the optimization of industrial processes $^{34,35}$ or in analytical work, ${ }^{36-40}$ it has scarcely been applied to electrochemical processes involving modified chemically electrodes. ${ }^{41-45}$ In this way, there is a demand for more applications of statistical design of experiments to electrochemical studies.

The aim of this work is to demonstrate the application of $\mathrm{TiO}_{2} /$ cellulose acetate matrix for the preparation of electrochemical sensors for NADH determination using a factorial design to achieve the best conditions of the electrochemical reversibility of the mediator. In order to achieve these tasks, two chemically modified electrodes formed by meldola blue and toluidine blue immobilized in $\mathrm{TiO}_{2}$ /cellulose acetate matrix forming $\mathrm{CA}-\mathrm{TiO}_{2}-\mathrm{MB}$ and $\mathrm{CA}-\mathrm{TiO}_{2}$ - $\mathrm{TB}$ were prepared. In order to achieve the best reversibility conditions of these electrodes, a full $2^{4}$ factorial design with two pseudo central points $(n=20$ experiments) was carried out. Afterwards, the best conditions of the optimization were utilized for the determination of NADH.

\section{Experimental}

\section{Solutions}

For the electrochemical measurements, double distilled water was employed throughout. Solutions of 0.2 to 1.0 mol L-1 $\mathrm{KCl}$ (Merck) were employed as supporting electrolyte.

\section{Preparation of the modified electrodes and electrochemical measurements}

An amount of $10.0 \mathrm{~g}$ of cellulose acetate was added to a reaction flask containing $40 \mathrm{~mL}$ of acetic anhydride (Merck) and $50 \mathrm{~mL}$ de acetone (Merck). The mixture was allowed to rest for $24 \mathrm{~h}$ at room temperature under dry nitrogen atmosphere. After that, viscous syrup was formed. Subsequently, $7.5 \mathrm{~mL}$ of titanium(IV) butoxide was added to this syrup $(100 \mathrm{~g})$ and magnetically stirred. The resulting syrup was slowly added to a flask containing about 1000 $\mathrm{mL}$ of double distilled water, with efficient stirring, in order to regenerate a fibrous material containing $\mathrm{TiO}_{2}$ immobilized on the cellulose acetate. The fibers were collected by filtration, washed with water and dried under vacuum at room temperature. Finally, the $\mathrm{CA}-\mathrm{TiO}_{2}$ hybrid material was dried at $60{ }^{\circ} \mathrm{C} .{ }^{14,46}$ The quantity of incorporated metal oxide in the matrix was determined by igniting it to $900{ }^{\circ} \mathrm{C}$ for $3 \mathrm{~h}$ and weighing the $\mathrm{TiO}_{2}$ residue, which resulted in $1.8 \mathrm{mmol} \mathrm{g}^{-1}$.
An amount of $0.5 \mathrm{~g}$ of $\mathrm{CA}-\mathrm{TiO}_{2}$ were added separately to $25.0 \mathrm{~mL}$ of $1.0 \times 10^{-3} \mathrm{~mol} \mathrm{~L}^{-1}$ meldola blue (Aldrich) or toluidine blue (Aldrich) solution at $\mathrm{pH}$ 6.0. The mixtures were shaken for $1 \mathrm{~h}$ and the resulting solids were filtered, washed several times with double distilled water and dried in an oven for $30 \mathrm{~min}$ at $60{ }^{\circ} \mathrm{C}$. The quantities of immobilized mediators were determined by elemental analysis. These materials were denominated here as CA$\mathrm{TiO}_{2}-\mathrm{MB}$ and $\mathrm{CA}-\mathrm{TiO}_{2}-\mathrm{TB}$, respectively.

The carbon paste electrodes were prepared by mixing the materials $\left(\mathrm{CA}-\mathrm{TiO}_{2}, \mathrm{CA}-\mathrm{TiO}_{2}-\mathrm{MB}\right.$ and $\left.\mathrm{CA}-\mathrm{TiO}_{2}-\mathrm{TB}\right)$ with analytical grade graphite in $1: 1(\mathrm{~m}: \mathrm{m})$ proportions with one drop of liquid paraffin as binder. These pastes were placed inside a glass tube with a cavity of $1 \mathrm{~mm}$ depth making an electrical contact with a $5 \mathrm{~mm}$ diameter platinum disk which was fused to the glass tube. The carbon paste electrodes made with these materials were used as the working electrodes. The other electrodes were a platinum wire as the counter electrode and a saturated calomel electrode (SCE) as the reference electrode. These three electrodes were placed inside a $100.0 \mathrm{~mL}$ conical thermostatically-controlled electrochemical cell at $25^{\circ} \mathrm{C}$. The solution degasification was carried-out by bubbling ultra-pure nitrogen in the electrochemical solution.

Cyclic voltammetry experiments involving factorial design were carried out on a potentiostat-galvanostat Radiometer model DEA 332 and the measurements for NADH determination were carried out in an Autolab PGSTAT20 potentiostat-galvanostat equipment from Eco Chemie (Utrecht, Netherlands) coupled to a microcomputer with GPES 4.9 software used for potential control, data acquisition and treatment.

The electro-catalytic oxidation of NADH ( $\beta$-nicotinamide adenine dinucleotide, reduced form, from Aldrich) on the $\mathrm{CA} / \mathrm{TiO}_{2} / \mathrm{MB}$ electrode was investigated by cyclic voltammetry and amperommetry techniques adding freshly prepared NADH solutions into the electrochemical cell containing $10 \mathrm{~mL}$ of the supporting electrolyte solution $1.0 \mathrm{~mol} \mathrm{~L}^{-1} \mathrm{KCl}$ and $\mathrm{pH}$ 7.0.

\section{EDS analysis}

The EDS image was obtained for $\mathrm{CA}-\mathrm{TiO}_{2}$ material dispersed on a double faced conducing tape on an aluminum support and coated with a thin film of gold using a Baltec SCD 050 Sputter Coater apparatus. The micrograph was obtained using a Jeol Scanning Electron Microscope, model JSM 5800, connected to a secondary electron detector and X-ray energy dispersive spectrometer (EDS) for elemental mapping in a Noran Instrument. The image was obtained with a magnification of $550 \mathrm{X}$. 


\section{Full factorial design}

Factorial design is employed to reduce the total number of experiments in order to achieve the best overall optimization of the system. ${ }^{34,35}$ The factorial design shows which factors have significant effects on the experimental response, as well as, how the effect of one factor varies with the levels of the other factors. Determinations of factor interactions could only be attained using statistical designs of experiments, ${ }^{34,35}$ since it can not be detected when the system optimization is carried-out by varying just one factor at a time and fixing the others.

For studying the electrochemical behavior of the modified electrodes, the potential difference between the cathodic and anodic peaks $(\Delta \mathrm{E})$ as well as the ratio between the anodic and cathodic currents (Ipa/Ipc) would depend on the acidity of the medium $(\mathrm{pH})$, support electrolyte concentration, scanning rate and type of electrode. In this study, a $2^{4}$ full factorial design with two pseudo-central points was used with the aim of determining the importance of three quantitative factors ( $\mathrm{pH}$, scan rate, and electrolyte concentration) and a qualitative one (dye compound immobilized) in order to find the best conditions of the reversibility of the meldola blue and toluidine blue adsorbed on the modified cellulose acetate surface. A full $2^{4}$ factorial design employed is given in Table 1. The factor levels were coded as -1 (low), 0 (central point) and 1 (high). ${ }^{34,35}$ For data treatment, the Statistica StatSoft 6.0 software was employed throughout in order to obtain the effects, coefficients, standard error of coefficients, and other statistical parameters of the fitted models.

\section{Results and Discussion}

\section{Characteristics of the material}

The elemental EDS analysis shows high titanium content over the cellulose acetate surface. The determined $\mathrm{Ti} / \mathrm{C}$ atomic ratio was 0.40 . Figure 1 shows the SEM and EDS images of the $\mathrm{CA}-\mathrm{TiO}_{2}$ material. The material seems to have a homogeneous surface, since agglomerated titania particles were not detected (Figure 1A). From the energy dispersive image (Figure 1B) it was possible to observe that the titania dispersion was very uniform. The bright points observed in Figure 1B are due to the titanium atoms (Ti $\mathrm{K} \alpha=4.5 \mathrm{keV})$. With the magnification used, the EDS image is indicating that the metal is homogenously dispersed over the cellulose acetate fiber.
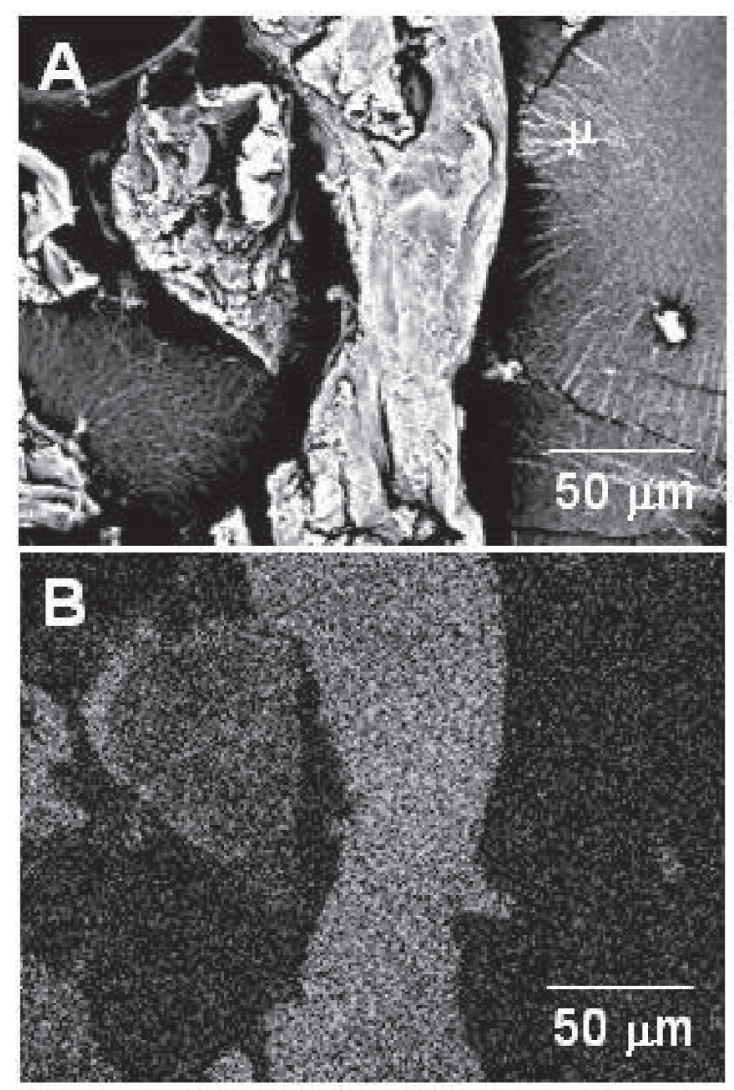

Figure 1. CA-TiO 2 micrographs. (A) SEM image; (B) EDS image.

Electrochemical characterization of chemically modified electrodes

The immobilizations of meldola blue and toluidine blue on $\mathrm{CA}-\mathrm{TiO}_{2}$ were made at $\mathrm{pH}$ 6.0, therefore, the forms of the immobilized dye compounds are $\mathrm{MB}^{+}$and $\mathrm{TB}^{+}$. Figure 2 shows the structures of organic dyes at various $\mathrm{pH}$ values. The immobilizations of meldola blue and toluidine blue on the $\mathrm{CA}-\mathrm{TiO}_{2}$ surface occurs by an ion exchange reaction, represented by the following reactions:

$$
\begin{gathered}
\mathrm{CA}-\mathrm{TiOH}+\mathrm{MB}^{+} \rightleftharpoons \mathrm{D} \text { CA-TiO-MB }+\mathrm{H}^{+} \text {and } \\
\mathrm{CA}-\mathrm{TiOH}+\mathrm{TB}^{+} \rightleftharpoons \mathrm{D} \mathrm{CA-TiO}-\mathrm{TB}+\mathrm{H}^{+}
\end{gathered}
$$

The amounts of meldola blue $\left(\mathrm{MB}^{+}\right)$and toluidine blue $\left(\mathrm{TB}^{+}\right)$adsorbed onto $\mathrm{CA}-\mathrm{TiO}_{2}$ were determined by $\mathrm{CHN}$ elemental analysis, resulting in $0.054 \pm 0.005$ and $0.133 \pm$ $0.004 \mathrm{mmol} \mathrm{g}^{-1}$, respectively.

Figures $3 \mathrm{~A}$ and $3 \mathrm{~B}$ show the cyclic voltammograms for $\mathrm{CA}-\mathrm{TiO}_{2}$ and $\mathrm{CA}-\mathrm{TiO}_{2}-\mathrm{MB}$ and Figures $4 \mathrm{~A}$ and $4 \mathrm{~B}$ the cyclic voltammograms for $\mathrm{CA}-\mathrm{TiO}_{2}$ and $\mathrm{CA}-\mathrm{TiO}_{2}-\mathrm{TB}$. The midpoint potentials, $\mathrm{E}_{\mathrm{m}}\left(\left[\mathrm{E}_{\mathrm{m}}=\left(\mathrm{E}_{\mathrm{pa}}+\mathrm{E}_{\mathrm{pc}}\right) / 2\right]\right.$, where $\mathrm{E}_{\mathrm{pa}}$ and $\mathrm{E}_{\mathrm{pc}}$ are the anodic and cathodic peak potentials, respectively) were $113 \mathrm{mV}$ for $\mathrm{CA}-\mathrm{TiO}_{2}-\mathrm{MB}$ and $93 \mathrm{mV}$ 
(A) Meldola Blue<smiles>CC(C)OCCNc1ccc2c(c1)Oc1ccc3ccccc3c1N2Cc1ccc2c(c1)Oc1ccc3ccccc3c1N2C</smiles>

(B) Toluidine blue<smiles>Cc1cc2nc3ccc(N(C)C)cc3sc-2cc1=N</smiles><smiles>[C+]#CC</smiles><smiles>Cc1cc2c(cc1N)Nc1ccc(N(C)C)cc1S2</smiles>

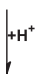<smiles>CN=c1ccc2nc3cc(C)c([NH])cc3sc-2c1</smiles>
$+2 \mathrm{e}^{-},+2 \mathrm{H}^{+}$

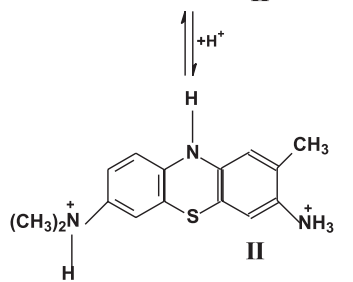

Figure 2. Structural formulas of meldola blue (A) and toluidine blue (B) in function of $\mathrm{pH}$.

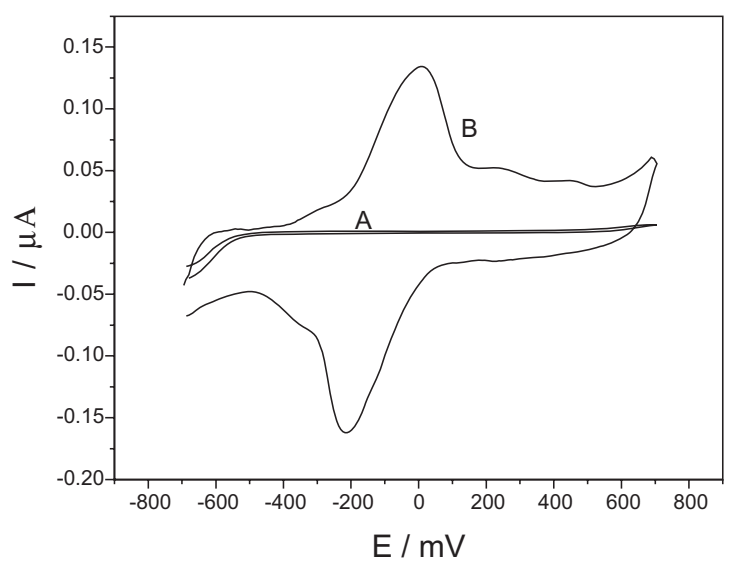

Figure 3. Cyclic voltammograms for: (A) $\mathrm{CA}_{-} \mathrm{TiO}_{2}$ and (B) $\mathrm{CA}_{-} \mathrm{TiO}_{2}-$ $\mathrm{MB}$, in scan rate at $10.0 \mathrm{mV} \mathrm{s}^{-1}$, pH 7.0 and $1.0 \mathrm{~mol} \mathrm{~L}^{-1} \mathrm{KCl}$ solution.

for $\mathrm{CA}-\mathrm{TiO}_{2}-\mathrm{TB}$. The small difference of the midpoint potentials observed for the materials $\mathrm{CA}-\mathrm{TiO}_{2}-\mathrm{MB}$ and $\mathrm{CA}-\mathrm{TiO}_{2}-\mathrm{TB}$ suggests that the molecules of the dyes are probably strongly involved by electrostatic attractions through the amines groups and/or by the nitrogens present in the heterocycles of the dye molecules with metal oxide dispersed over the cellulose acetate fiber. ${ }^{47-49}$

Figure 5 shows the stability of the electrodes when several redox cycles were performed in $1.0 \mathrm{~mol} \mathrm{~L}^{-1} \mathrm{KCl}$

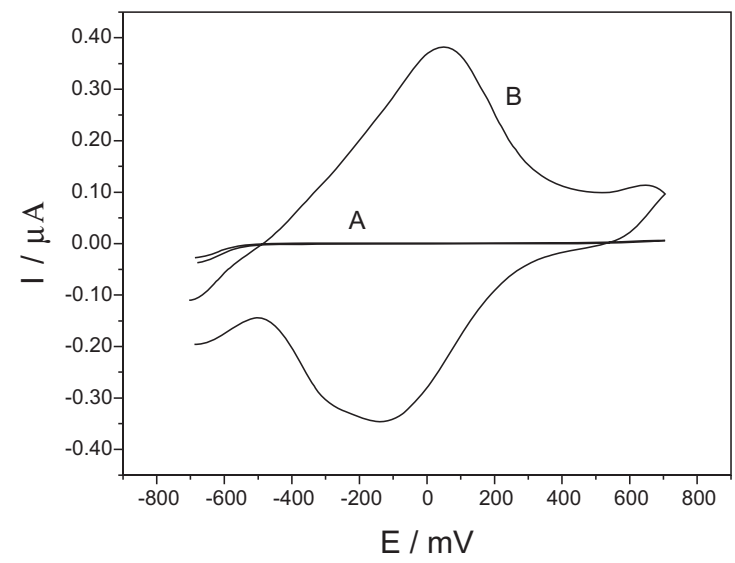

Figure 4. Cyclic voltammograms for: (A) $\mathrm{CA}-\mathrm{TiO}_{2}$ and (B) $\mathrm{CA}-\mathrm{TiO}_{2}-$ $\mathrm{TB}$, in scan rate at $10.0 \mathrm{mV} \mathrm{s}^{-1}, \mathrm{pH} 7.0$ and $1.0 \mathrm{~mol} \mathrm{~L}^{-1} \mathrm{KCl}$ solution.

supporting electrolyte solution. The dye species impregnated at the electrode surfaces could be leached from the electrode during several oxidation and reduction cycles. As can be seen, after 120 cycles for the $\mathrm{CA}-\mathrm{TiO}_{2}-$ $\mathrm{MB}$ and $\mathrm{CA}-\mathrm{TiO}_{2}-\mathrm{TB}$ electrodes, the anodic peak current and cathodic peak current kept practically constant, using $1.0 \mathrm{~mol} \mathrm{~L}^{-1} \mathrm{KCl}$ as supporting electrolyte and $\mathrm{pH} 7.0$, showing that the dyes were not leached out from the matrix surface owing to their large affinities. In relation to the cathodic peak current, the same behaviour was verified. The studies of chemical stability indicate that the electrodes present good performance when operating for two days, using $8 \mathrm{~h}$ per day and maintained overnight in $0.01 \mathrm{~mol} \mathrm{~L}^{-1} \mathrm{KCl}$ solution. At this condition, a decrease of $7 \%$ was observed in the current intensities. The electrodes can be considered as having good chemical stability allowing their use for reasonable time without significant variation in the response. In addition, modified carbon paste electrodes are easily prepared and can be obtained in a short period of time.

\section{Full factorial design for optimization of the electrochemical system}

The optimization of voltammetric conditions to employ a CME in an electrochemical system in order to achieve the best conditions for reversibility will depend on several factors, such as the acidity of medium $(\mathrm{pH})$, the support electrolyte concentration, scan rate $\left(\mathrm{mV} \mathrm{s}^{-1}\right)$, the kinds of chemically modified electrodes, the temperature, etc. The optimization of all these variables using the univariate procedure is very tedious, because there is the need to vary a factor one at a time and fixing the others. The disadvantage of this univariate procedure is that the best conditions could not be attained, because 


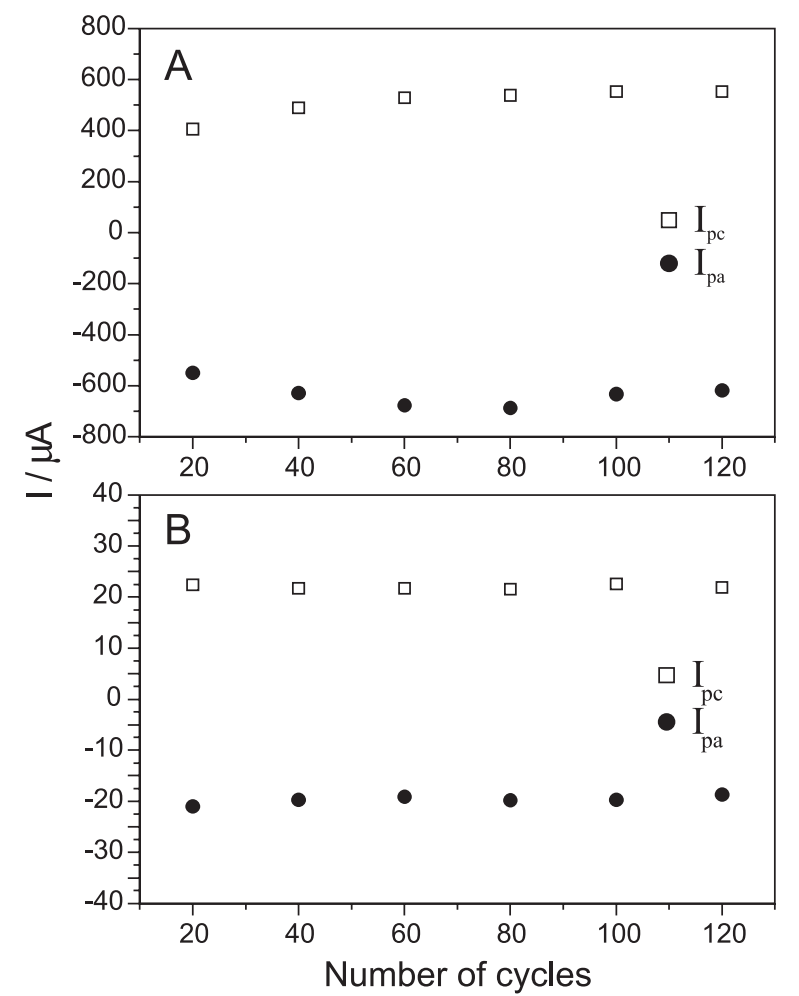

Figure 5. Peak currents for (A) $\mathrm{CA}-\mathrm{TiO}_{2}-\mathrm{TB}$ and (B) $\mathrm{CA}-\mathrm{TiO}_{2}-\mathrm{MB}$ as function of number of redox cycles under scan rate at $10.0 \mathrm{mV} \mathrm{s}^{-1}, \mathrm{pH}$ 7.0, in $1.0 \mathrm{~mol} \mathrm{~L}^{-1} \mathrm{KCl}$ solution. ( $\square$ ) cathodic peak current. (-) anodic peak current. the interactions among all the factors have been neglected. In addition the total number of experiments to be carriedout in the univariate procedure is much higher when compared with statistical design of experiments.

In this work, a $2^{4}$ full factorial design with two pseudocentral points ( $\mathrm{n}=20$ experiments) for the electrochemical system (Table 1) was performed. The factors chosen for the optimization procedure are those that could affect the reversibility of electron transfer, such as: $\mathrm{pH}$ of the solution, $\mathrm{KCl}$ concentration $\left(\mathrm{mol} \mathrm{L}^{-1}\right)$, scan rate $\left(\mathrm{mV} \mathrm{s}^{-1}\right)$, and type of organic dye immobilized on the matrix (Ca$\mathrm{TiO}_{2}-\mathrm{MB}$ and $\left.\mathrm{CA}-\mathrm{TiO}_{2}-\mathrm{TB}\right)$. Two responses of the system were investigated: the peak potential separation, $\Delta \mathrm{E}$ $\left[\Delta \mathrm{E}=\mathrm{E}_{\mathrm{pa}}-\mathrm{E}_{\mathrm{pc}}\right]$ (see Table 1) and current ratio, $\mathrm{I}_{\mathrm{pa}} / \mathrm{I}_{\mathrm{pc}}$ (where $\mathrm{I}_{\mathrm{pa}}$ and $\mathrm{I}_{\mathrm{pc}}$ are the anodic and cathodic current intensities, respectively), (see Table 1). The parameters were analyzed using the Statistica StatSoft 6.0 software, which calculates the main and the interactions among the factors, the standard error of the coefficients and the probability of each term.

By analyzing Table 2 (peak potential separation response, $\Delta \mathrm{E}$ ), it was verified that two main factors and two interactions were significant at a $5 \%$ of probability level $(\mathrm{p}<0.05)$. All the effects and interactions that presented probability lower than 0.05 were significant.

Table 1. Optimization of the electrochemical system using $2^{4}$ factorial design with two pseudo-central points (20 experiments)

\begin{tabular}{|c|c|c|c|c|c|c|}
\hline \multicolumn{7}{|c|}{ Factors } \\
\hline Experiment & A & B & $\mathrm{C}$ & $\mathrm{D}$ & $\Delta \mathrm{E} / \mathrm{mV}$ & $\mathrm{Ipa} / \mathrm{Ipc}$ \\
\hline 1 & -1 & -1 & -1 & -1 & 444 & 0.955 \\
\hline 2 & 1 & -1 & -1 & -1 & 121 & 0.956 \\
\hline 3 & -1 & 1 & -1 & -1 & 215 & 0.987 \\
\hline 4 & 1 & 1 & -1 & -1 & 223 & 0.956 \\
\hline 5 & -1 & -1 & 1 & -1 & 171 & 0.935 \\
\hline 6 & 1 & -1 & 1 & -1 & 314 & 0.954 \\
\hline 7 & -1 & 1 & 1 & -1 & 496 & 1.006 \\
\hline 8 & 1 & 1 & 1 & -1 & 359 & 0.987 \\
\hline 9 & -1 & -1 & -1 & 1 & 611 & 1.002 \\
\hline 10 & 1 & -1 & -1 & 1 & 333 & 1.008 \\
\hline 11 & -1 & 1 & -1 & 1 & 171 & 0.975 \\
\hline 12 & 1 & 1 & -1 & 1 & 193 & 0.975 \\
\hline 13 & -1 & -1 & 1 & 1 & 703 & 0.965 \\
\hline 14 & 1 & -1 & 1 & 1 & 678 & 1.002 \\
\hline 15 & -1 & 1 & 1 & 1 & 460 & 0.965 \\
\hline 16 & 1 & 1 & 1 & 1 & 496 & 1.001 \\
\hline 17 & 0 & 0 & 0 & -1 & 444 & 1.003 \\
\hline 18 & 0 & 0 & 0 & 1 & 551 & 0.987 \\
\hline 19 & 0 & 0 & 0 & -1 & 352 & 1.003 \\
\hline \multirow[t]{2}{*}{20} & 0 & 0 & 0 & 1 & 528 & 0.972 \\
\hline & & & & \multicolumn{3}{|c|}{ Levels } \\
\hline \multicolumn{4}{|l|}{ Factors } & -1 & 0 & 1 \\
\hline A & \multicolumn{3}{|c|}{$\mathrm{pH}$} & 3.0 & 5.0 & 7.0 \\
\hline B & \multicolumn{3}{|c|}{$\mathrm{KCl}$ concentration / $\left(\mathrm{mol} \mathrm{L}^{-1}\right)$} & 0.2 & 0.6 & 1.0 \\
\hline $\mathrm{C}$ & \multicolumn{3}{|c|}{ Scan rate $/\left(\mathrm{mV} \mathrm{s}^{-1}\right)$} & 10.0 & 30.0 & 40.0 \\
\hline $\mathrm{D}$ & \multicolumn{3}{|c|}{ Type of electrode } & $\mathrm{CA}-\mathrm{TiO}_{2}-\mathrm{MB}$ & \multicolumn{2}{|c|}{$\mathrm{CA}-\mathrm{TiO}_{2}-\mathrm{TB}$} \\
\hline
\end{tabular}


The significant main effects and interactions were $(\mathrm{p}<$ 0.05): $\mathrm{C}, \mathrm{D}$, interactions $\mathrm{B} \times \mathrm{D}$ and $\mathrm{A} \times \mathrm{B} \times \mathrm{C}$ where $\mathrm{A}: \mathrm{pH}$; $\mathrm{B}$ : $\mathrm{KCl}$ concentration; $\mathrm{C}$ : scan rate $\left(\mathrm{mV} \mathrm{s}^{-1}\right)$ and $\mathrm{D}$ : type of electrode $\left(\mathrm{Ca}-\mathrm{TiO}_{2}-\mathrm{MB}\right.$ and $\left.\mathrm{CA}-\mathrm{TiO}_{2}-\mathrm{TB}\right)$. All other interactions presented probability higher than $5 \%$ being not significant. In addition, the adjusted statistical model for $\Delta \mathrm{E}$ using the chemically modified electrodes could be expressed by the equation:

$$
\begin{array}{r}
\Delta \mathrm{E}=374.25+85.37 \times \mathrm{C}+79.25 \times \mathrm{D} \\
-78.00 \times \mathrm{B} \times \mathrm{D}-53.12 \times \mathrm{A} \times \mathrm{B} \times \mathrm{C}
\end{array}
$$

Being the values of the factors coded, and its levels valid only for the levels described in Table 1. The positive values of effects meant that an increase in their levels leaded to an increase in separation potentials of anodic and cathodic peaks $(\Delta \mathrm{E})$ leading to a worst reversibility results, since the aim of this work it to attain the minimum value of separation potential between anodic and cathodic peaks, on the other hand, the negative values of the effects, lead to a diminution of the response $(\Delta \mathrm{E})$, when their levels were increased, suggesting that better reversibility conditions could be attained.

In Figure 6 is presented the Pareto Chart of standardized effects at $p=0.05$. All the standardized effects were in absolute values. All the values that presented an absolute value higher $(p=0.05)$, which were located at right of the dash line, were significant. The absolute standardized value of the effect of each factor and its interaction appeared at the right of each bar.

Analyzing the graph of Figure 6 and the values of Table 2, it can be inferred that the scan rate of the voltammogram was the most important variable of the overall optimization of the system. According to the theory of cyclic voltammetry, in a reversible electrode process, the peak potential, Ep, is independent of scan rate. ${ }^{50}$ At the same time, in a totally irreversible process there is a linear relationship between the peak potential

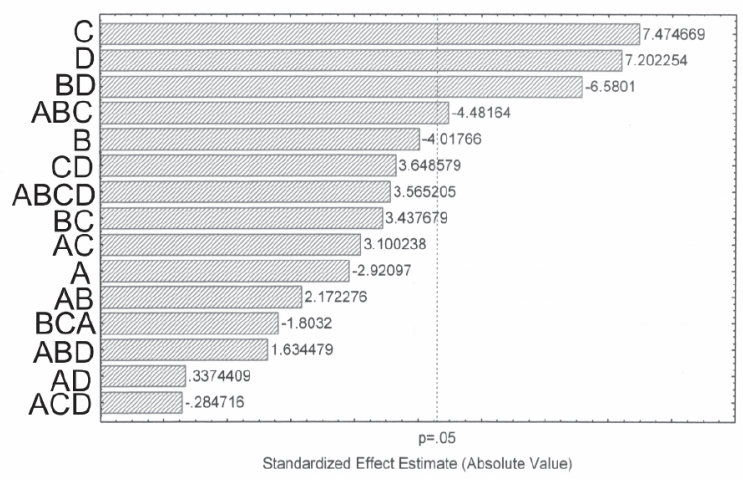

Figure 6. Pareto chart plot of standardized effects at $\mathrm{p}=0.05$. and the logarithm of the scan rate. This behaviour can be attributed to the fact that electron transfer of the mediator is slow, favouring a more reversible system at lower scan rate. Although the electrode processes were diffusion controlled, the rate of charge transport and the electrode reaction were rather slow. Because of the slow rates of charge transport, when the potential was scanned at a low rate, the electrode reaction could reach completion, and the cyclic voltammogram exhibited nearly reversible features. But when potential was scanned at higher rates, the electrode reaction could not reach completion in time: hence, the cyclic voltammogram exhibited quasi-reversible or irreversible features, and this electrode process was controlled by both the electrode reaction and mass diffusion.

The second important factor for overall optimization of the electrochemical system was the type of chemically modified electrode. The positive value of its coefficient, meant that the when the chemically modified electrode was changed from $\mathrm{CA}-\mathrm{TiO}_{2}-\mathrm{MB}$ to $\mathrm{CA}-\mathrm{TiO}_{2}-\mathrm{TB}$ the separation between the anodic and cathodic peaks was increased, i.e., the reversibility was worsen. This result indicates that the meldola blue is a better electrochemical mediator when compared with toluidine blue. Observing

Table 2. Factorial Fit: $\Delta \mathrm{E}$ versus $\mathrm{pH}$; electrolyte concentration; scan rate; type of electrode

\begin{tabular}{lcccc}
\hline Term & Effect & Coefficient & S.E. of Coefficient & $\mathrm{P}$ \\
\hline Constant & & 374.25 & 11.85 & 0.000 \\
Main effects & & & & \\
$\mathrm{A}$ & -69.25 & -34.62 & 11.85 & 0.100 \\
$\mathrm{~B}$ & -95.25 & -47.63 & 11.85 & 0.057 \\
$\mathrm{C}$ & 170.75 & 85.37 & 11.85 & 0.019 \\
$\mathrm{D}$ & 158.50 & 79.25 & 10.60 & 0.017 \\
Interactions of two factors & & & \\
$\mathrm{A} \times \mathrm{B}$ & 51.50 & 25.75 & 11.85 & 0.162 \\
$\mathrm{~A} \times \mathrm{C}$ & 73.50 & 36.75 & 11.85 & 0.090 \\
$\mathrm{~A} \times \mathrm{D}$ & 8.00 & 4.00 & 11.85 & 0.768 \\
$\mathrm{~B} \times \mathrm{C}$ & 81.50 & 40.75 & 11.85 & 0.075 \\
$\mathrm{~B} \times \mathrm{D}$ & -156.00 & -78.00 & 11.85 & 0.022 \\
$\mathrm{C} v \mathrm{D}$ & 86.50 & 43.25 & 11.85 & 0.068 \\
Interaction of three factors & & & \\
$\mathrm{A} \times \mathrm{B} \times \mathrm{C}$ & -106.25 & -53.12 & 11.85 & 0.046 \\
$\mathrm{~A} \times \mathrm{B} \times \mathrm{D}$ & 38.75 & 19.38 & 11.85 & 0.244 \\
$\mathrm{~A} \times \mathrm{C} \times \mathrm{D}$ & -6.75 & -3.37 & 11.85 & 0.803 \\
$\mathrm{~B} \times \mathrm{C} \times \mathrm{D}$ & -42.75 & -21.37 & 11.85 & 0.213 \\
Interaction of four factors & & & \\
$\mathrm{A} \times \mathrm{B} \times \mathrm{C} \times \mathrm{D}$ & 46.50 & 23.25 & 11.85 & 0.104 \\
central point & 94.50 & 22.49 & 0.025 & \\
\hline
\end{tabular}

\begin{tabular}{lc}
\hline Factors & $\mathrm{pH}$ \\
$\mathrm{A}$ & Electrolyte concentration \\
$\mathrm{B}$ & Scan rate \\
$\mathrm{C}$ & Type of electrode \\
$\mathrm{D}$ & \\
\hline
\end{tabular}


Figure 2, the meldola blue presents three arene rings plus one heterocycle aromatic ring, on the other hand toluidine blue presents only two arene rings plus one heterocyle aromatic ring. Higher is the number of aromatic rings better is the electron transfer in electrochemical reactions. $^{51}$

The third important factor in order of importance for overall optimization of the electrochemical system was the interaction of two factors $\mathrm{B} \times \mathrm{D}([\mathrm{KCl}] \times$ type of electrode). The interaction between these two factors is antagonistic, i.e., when the $\mathrm{KCl}$ concentration was changed from the lower level $(-)$ to its higher level $(+)$ and the electrode was changed from meldola blue to toluidine blue, the $\Delta \mathrm{E}$ becomes lower relative to the sum of peak separation for isolated changes in these factors. In this way, with a simultaneous change in $\mathrm{KCl}$ concentration from 0.2 to $1.0 \mathrm{~mol} \mathrm{~L}^{-1}$ and a change in type of electrode from $\mathrm{Ca}-\mathrm{TiO}_{2}-\mathrm{MB}$ and $\mathrm{CA}-\mathrm{TiO}_{2}-\mathrm{TB}$ an decrease in the peak separation of about $-156 \mathrm{mV}$ below that owing to the principal effects, $-95.25+$ $158.50=63.25 \mathrm{mV}$ is observed. Only multivariate procedures can detect interaction effects. This information would not be acquired in a univariate optimization of the electrochemical system.

The fourth important factor was the interaction of three factors $\mathrm{A} \times \mathrm{B} \times \mathrm{C}(\mathrm{pH} \times \mathrm{KCl}$ concentration $\mathrm{x}$ scan rate). It should be stressed the importance of the factorial design to achieve the best conditions of the reversibility of the electrochemical system. If the optimization of system were carried-out in a univariate mode, a small increase of $\mathrm{pH}$ solution with a small increase in the electrolyte solution associated with a small increase in the scan rate (changes provoked by a possible drifting of the potentiostat) would lead to a misinterpretation of the results achieved with the univariate procedure. Probably the experimenter would remake all the measurements, because one would not perceive that the synergistic effect caused by a small variation of these factors together would lead to an unexplained improvement in the $\Delta \mathrm{E}$. These results could not be explained using the univariate procedure of optimization of the system.

For the Ipa/Ipc ratio response, it was observed that no effect values appear to be significant at the $95 \%$ confidence level except for the $\mathrm{B} \times \mathrm{D}$ and $\mathrm{A} \times \mathrm{B} \times \mathrm{C}$ interactions that influence significantly. Both chemically modified electrodes $\mathrm{CA}_{-} \mathrm{TiO}_{2}-\mathrm{MB}$ and $\mathrm{CA}-\mathrm{TiO}_{2}-\mathrm{TB}$ presented an Ipa/Ipc ratio response close to the unity (see Table 1), being both chemically modified electrodes suitable for being employed as electrochemical mediators.
Application of $\mathrm{CA}-\mathrm{TiO}_{2}-\mathrm{MB}$ as amperometric sensor for $\mathrm{NADH}$ determination

The electrochemical oxidation of $\beta$-nicotinamide adenine dinucleotide (NADH) is of great interest since there is a very large number of dehydrogenases that require this cofactor in their enzymatic reactions. NADH dependent dehydrogenases catalyse the oxidation of compounds such as aldehydes, alcohols and carbohydrates that are of immense interest in analytical chemistry. ${ }^{52}$

After optimizing the best reversibility condition using statistical design of experiments, the electrocatalytic properties of $\mathrm{CA}-\mathrm{TiO}_{2}-\mathrm{MB}$ electrode were investigated for NADH determination using cyclic voltammetry. Figure 7 reveals the electro-catalytic properties of $\mathrm{CA}^{-\mathrm{TiO}_{2}}$-MB to oxidize NADH $(7.69 \times$ $10^{-4} \mathrm{~mol} \mathrm{~L}^{-1}$ ) at scan rate of $10.0 \mathrm{mV} \mathrm{s}^{-1}$, in a medium, containing $1.0 \mathrm{~mol} \mathrm{~L}^{-1} \mathrm{KCl}$ as supporting electrolyte and keeping the $\mathrm{pH}$ at 7.0 . As can be seen, at $-0.07 \mathrm{~V}$ versus $\mathrm{SCE}$, an anodic wave was shown, indicating the electrochemical oxidation of NADH. The curves obtained with NADH added to the electrolyte solution, in comparison with that without NADH, shows that the anodic wave of the mediator is increased while the cathodic wave is decreased, according to the reported mechanism for electrocatalytic oxidation of NADH by this kind of mediator. ${ }^{53}$

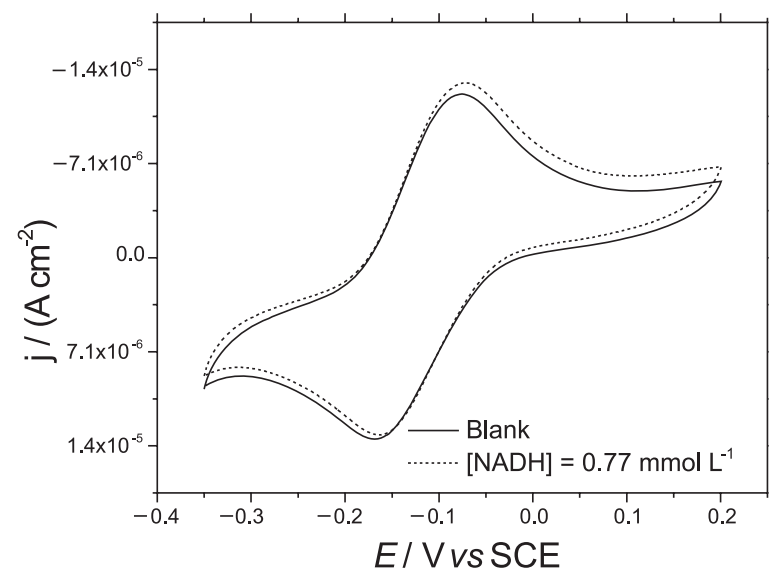

Figure 7. Cyclic voltammograms for $\mathrm{CA}-\mathrm{TiO}_{2}-\mathrm{MB}$ electrode obtained in the absence (-) and presence of $7.69 \times 10^{-4} \mathrm{~mol} \mathrm{~L}^{-1} \mathrm{NADH}(---)$. Measurements made with a scan rate of $10.0 \mathrm{mV} \mathrm{s}^{-1}, \mathrm{pH} 7.0$, in $1.0 \mathrm{~mol} \mathrm{~L}^{-1}$ $\mathrm{KCl}$ solution.

Chronoamperometric experiments were carried out in order to verify if the $\mathrm{CA}-\mathrm{TiO}_{2}-\mathrm{MB}$ electrode could be employed as an amperometric sensor for NADH determination. $\mathrm{E}_{\text {ap }}$ was chosen by measuring the intensities of $\mathrm{j}_{\mathrm{pa}}$ for an NADH concentration of $7.69 \times$ $10^{-4} \mathrm{~mol} \mathrm{~L}^{-1}$ at $\mathrm{pH} 7.0$ in $1.0 \mathrm{~mol} \mathrm{~L}^{-1} \mathrm{KCl}$. The 
investigation showed that the highest intensity of $j_{p a}$ was observed for potential values higher than $0.01 \mathrm{~V}$ and its potential was set at $0.02 \mathrm{~V} v$ s SCE. Figure 8 shows chronoamperometric curves obtained for CA$\mathrm{TiO}_{2}-\mathrm{MB}$ for various NADH concentrations (up to 1.82 $\left.\times 10^{-3} \mathrm{~mol} \mathrm{~L}^{-1}\right)$. As can be seen, increasing concentrations of the NADH leaded to increasing density of currents, indicating that a higher amount of this substract was oxidized when its concentration were increased. Therefore, the modified electrode $\mathrm{CA}-\mathrm{TiO}_{2}-$ MB could be successfully employed for NADH determinations.

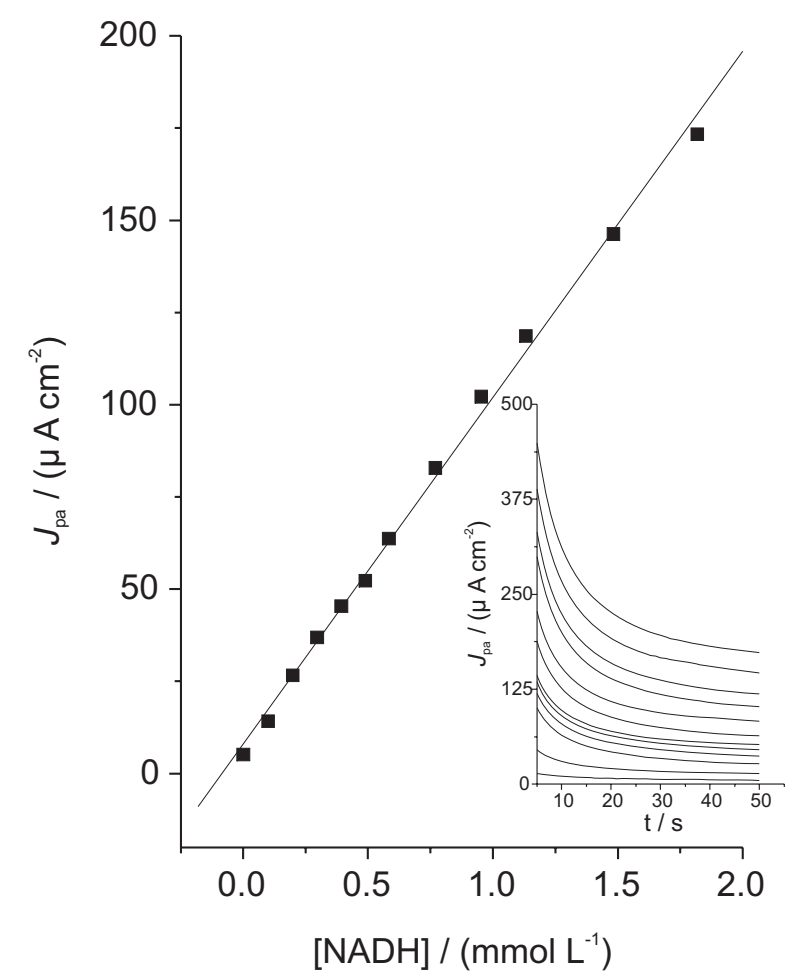

Figure 8. Chronoamperograms for $\mathrm{CA}-\mathrm{TiO}_{2}-\mathrm{MB}$ electrode in various NADH concentrations (up to $1.82 \times 10^{-3} \mathrm{~mol} \mathrm{~L}^{-1}$ ). Measurements made at $\mathrm{pH} 7.0$, in $1.0 \mathrm{~mol} \mathrm{~L}^{-1} \mathrm{KCl}$ solution and $E_{\text {ap }}=0.02 \mathrm{~V} v s$ SCE.
The analytical calibration curve achieved for NADH determination using the modified electrode $\mathrm{CA}-\mathrm{TiO}_{2}-\mathrm{MB}$ and applying an anodic potential $E_{\text {ap }}=0.02 \mathrm{~V} v s \mathrm{SCE}$ were: $\mathrm{j}_{\mathrm{pa}}=1.29( \pm 0.24)+15023.56( \pm 270)[\mathrm{NADH}]\left(\mathrm{r}^{2}=\right.$ $0.9968, \mathrm{n}=12$ ) where $\mathrm{j}_{\mathrm{pa}}$ is the anodic current density $\left(\mu \mathrm{A} \mathrm{cm}^{-2}\right)$ and $[\mathrm{NADH}]$ is the $\mathrm{NaDH}$ concentration (mmol $\left.\mathrm{L}^{-1}\right)$. The achieved detection limit (3 standard deviation of the blank divided by the slope of calibration curve) was $0.1 \mu \mathrm{mol} \mathrm{L}{ }^{-1}$, presenting good sensitivity of this electrode for NADH dosage.

The performance of the $\mathrm{CA}-\mathrm{TiO}_{2}-\mathrm{MB}$ modified electrode in comparison with other amperometric sensors based on carbon paste electrodes for the determination for NADH was shown in Table 3. As can be observed, the $\mathrm{CA}-\mathrm{TiO}_{2}-\mathrm{MB}$ modified electrode presented good performance with low detection limit and high sensitivity, showing the potentiality the $\mathrm{CA}-\mathrm{TiO}_{2}-\mathrm{MB}$ modified electrode as a sensor for NADH.

\section{Conclusions}

This study shows that the factorial design provides an efficient approach to plan experiments involving meldola blue (MB) and toluidine blue (TB) dyes adsorbed on modified cellulose acetate surface for optimization of reversibility characteristics of the adsorbed mediator. The full factorial design used here, allowed a simultaneous investigation of four selected factors by executing only twenty experiments. In this way multivariate factorial designs are more time saving than univariate ones. The best electrochemical reversibility conditions were: using the $\mathrm{CA}-\mathrm{TiO}_{2}-\mathrm{MB}$ electrode, $\mathrm{pH} 7.0,1.0 \mathrm{~mol} \mathrm{~L}^{-1} \mathrm{KCl}$ as supporting electrolyte, at scan rate of $10.0 \mathrm{mV} \mathrm{s}^{-1}$. Afterwards, the $\mathrm{CA}-\mathrm{TiO}_{2}-\mathrm{MB}$ was employed for $\mathrm{NADH}$ determination using chronoamperometry as an electroanalytical technique achieving a very good detection limit $(0.1 \mu \mathrm{mol} \mathrm{L}-1)$.

Table 3. Performance of the $\mathrm{CA}-\mathrm{TiO}_{2}-\mathrm{MB}$ modified electrode in comparison with others amperometric sensors prepared in different solid supports for the determination of NADH

\begin{tabular}{|c|c|c|c|c|c|}
\hline Electrode & Solid Support & $\begin{array}{l}\text { Linear range / } \\
\left(\mathrm{mmol} \mathrm{L}^{-1}\right)\end{array}$ & $\begin{array}{l}\text { Detection limit / } \\
\quad\left(\mu \mathrm{mol} \mathrm{L} \mathrm{L}^{-1}\right)\end{array}$ & $\begin{array}{c}\text { Sensitivity/ } \\
\left(\mathrm{mA} \mathrm{cm}^{-2} \mathrm{~L} \mathrm{~mol}^{-1}\right)\end{array}$ & Reference \\
\hline $\mathrm{CA}-\mathrm{TiO}_{2}-\mathrm{MB}$ & cellulose acetate & $0.05-2.0$ & 0.1 & 15 & this work \\
\hline CPE/SNPDA & Silica gel & $0.04-0.8$ & 7.1 & 24.2 & 22 \\
\hline $\mathrm{SiO}_{2} / \mathrm{ZrO}_{2} / \mathrm{Sb}_{2} \mathrm{O}_{5} / \mathrm{MB}$ & sol-gel & & 36 & & 24 \\
\hline $\mathrm{ZPMB}$ & Phosphate & $0.1-2.0$ & 10 & & 54 \\
\hline ZPNB & Phosphate & $0.1-2.0$ & 5 & & 54 \\
\hline SiSbMeB & sol-gel & $0.1-0.6$ & 7 & 4.6 & 55 \\
\hline SiSbMB & sol-gel & $0.1-0.6$ & 25 & 1.8 & 55 \\
\hline SiSbMTB & sol-gel & $0.4-1$ & 42 & 0.5 & 55 \\
\hline CPE/SNNB & Silica gel & $0.01-0.52$ & & 18 & 56 \\
\hline $\mathrm{C}: \mathrm{ZrP}: \mathrm{NB}$ & Phosphate & & & $19.2-60.8$ & 57 \\
\hline C:ZrP:MV & Phosphate & & & $18.4-50.9$ & 57 \\
\hline
\end{tabular}




\section{Acknowledgments}

The authors are grateful to the Reviewers for the suggestions; to Pró-Reitoria de Pesquisa da Universidade Federal do Rio Grande do Sul (Propesq-UFRGS); to Fundação de Amparo à Pesquisa do Estado do Rio Grande do Sul (FAPERGS); to Fundação de Amparo à Pesquisa do Estado de São Paulo (FAPESP); to Coordenação de Aperfeiçoamento de Pessoal de Nível Superior (CAPES); to Conselho Nacional de Desenvolvimento Científico e Tecnológico ( $\mathrm{CNPq}$ ); to Ministério de Ciência e Tecnologia (MCT) for financial support and fellowships. We also thank the CME-UFRGS for the use of the SEM.

\section{References}

1. Dempsey, E.; Wang, J.; Wollenberger, V.; Ozsoz, M.; Smith, M. R.; Biosens. Bioelectron. 1992, 715, 323.

2. Walcarius, A.; Electroanalysis 1998, 10, 1217.

3. Collinson, M. M.; Crit. Rev. Anal. Chem. 1999, 29, 289.

4. Walcarius, A.; Anal. Chim. Acta 1999, 384, 1.

5. Gushikem, Y.; Toledo, E. A. In Polymer Interfaces and Emulsions; Esumi, K., ed.; Marcel Dekker: New York, 1999, ch. 3, p. 509.

6. Ullmann's Encyclopedia of Industrial Chemistry, $5^{\text {th }}$ ed., VCH: Germany, 1986, vol. A5, pp. 438-459.

7. Wara, N. M.; Francis, L. F.; Velamakanni, B. V.; J. Membr. Sci. 1995, 104, 43.

8. Kurokawa, Y.; Ueno, K.; J. Appl. Polym. Sci. 1982, 27, 621.

9. Kurokawa, Y.; J. Membr. Sci. 1996, 114, 1.

10. Lazarin, A. M.; Borgo, C. A.; Gushikem, Y.; J. Membr. Sci. 2003, 221, 175.

11. Murtinho, D.; Lagoa, A. R.; Garcia, F.A. P.; Gil, M. H.; Cellulose 1998, 5, 299.

12. Gushikem, Y.; Campos, E.A.; J. Braz. Chem. Soc. 1998, 9, 273.

13. Kubota, L.T.; Gushikem, Y.; J. Electroanal. Chem. 1993, 362, 219.

14. Dias, S. L. P.; Gushikem, Y.; Ribeiro, E.S.; Benvenutti, E.V.; J. Electroanal. Chem. 2002, 523, 64.

15. Gorton, L.; Torstensson, A.; Jaegfeldt, H.; Johansson, G.; J. Electroanal. Chem. 1984, 161, 103.

16. Chenault, H. K.; Whitesides, G.M.; Appl. Biochem. Biotechnol. 1987, 14, 147.

17. Jaegfedt, H.; Torstensson, A.; Gorton, L.; Tohansson. G.; Anal. Chem. 1981, 53, 1979.

18. Tse, D. C-S.; Kuwana, T.; Anal. Chem. 1978, 50, 1315.

19. Pereira, A. C.; Santos, A. S.; Kubota, L.T.; Electrochim. Acta 2003, 48, 3541.

20. Curulli, A.; Carelli, I.; Trischitta, O.; Palleschi, G.; Talanta 1997, 44, 1659.

21. Zaitseva, G.; Gushikem, Y.; Ribeiro, E. S.; Rosatto, S. S.; Electrochim. Acta 2002, 47, 1469.
22. Persson. B.; J. Electroanal. Chem. 1990, 287, 61.

23. Rivera, N.; Colon, Y.; Guadalupe, A.R.; Bioelectrochem. Bioenerg. 1994, 34, 169.

24. Malinauskas, A.; Ruzgas, T.; Gorton, L.; J. Electroanal. Chem. 2000, 484, 55.

25. Mao, L.; Yamamoto, K.; Talanta 2000, 51, 187.

26. Munteanu, F-D.; Okamoto, Y.; Gorton, L.; Anal. Chim. Acta 2003, 476, 43.

27. Sprules, S. D.; Hartley, I. C.; Wedge, R.; Hart, J. P.; Pittson, R.; Anal. Chim. Acta 1996, 329, 215.

28. Sprules, S. D.; Hart, J. P.; Wring, S. A.; Pittson, R.; Anal. Chim. Acta 1995, 304, 17.

29. Sprules, S. D.; Hart, J. P.; Pittson, R.; Wring, S. A.; Electroanalysis 1996, 8, 539.

30. Molina, C. R.; Boujtita, M.; El Murr, N.; Anal. Chim. Acta 1999, 401, 155.

31. Abass, A. K.; Hart, J. P.; Cowell, D. C.; Chapell, A.; Anal. Chim. Acta 1998, 373, 1.

32. Sandström, K. J. M.; Newman, J.; Sunesson, A.-L.; Levin, J.O.; Turner, A. P. F.; Sens. Actuators, B 2000, 70, 182.

33. Wedge, R.; Pemberton, R. M.; Hart, J. P.; Luxton, R.; Analysis 1999, 27, 570 .

34. Barros Neto, B. de; Scarmínio, I. S.; Bruns, R. E.; Como Fazer Experimentos: Pesquisa e Desenvolvimento na Ciência e na Indústria, Editora da Unicamp: Campinas, SP, 2001.

35. Box, G. E. P.; Hunter, W. G.; Hunter, J. S.; Statistics for Experimenters-An Introduction to Design, Data Analysis and Model Building, John Wiley \& Sons: New York, 1978.

36. Ruiz, V. S. O.; Dias, S. L. P.; Gushikem, Y.; Bruns, R. E.; Airoldi, C.; J. Sol. State Chem. 2004, 177, 675.

37. Brasil, J. L.; Martins, L. C.; Ev, R. R.; Dupont, J.; Dias, S. L. P.; Sales, J. A. A.; Airoldi, C.; Lima, E. C.; Int. J. Environ. Anal. Chem. 2005, 85, 475.

38. Brasil, J. L.; Ev, R.R.; Milcharek, C. D.; Martins, L. C.; Pavan, F. A.; Santos Júnior, A. A.; Dias, S. L. P.; Dupont, J.; Noreña, C. P. Z.; Lima, E. C.; J. Hazard. Mater. 2006, 133, 143.

39. Pavan, F. A.; Gushikem, Y.; Mazzocato, A. C.; Dias, S. L. P.; Lima, E. C.; Dyes and Pigments 2007, 72, 256.

40. Lima, E. C.; Royer, B.; Vaghetti, J. C. P.; Brasil, J. L.; Simon, N. M.; Santos Júnior, A. A.; Pavan, F. A.; Dias, S. L. P.; Benvenutti, E. V.; Silva, E. A.; J. Hazard. Mater. 2007, 140, 211.

41. Scotti, R.; Lima, E. C.; Benvenutti, E. V.; Piatnicki, C. M. S.; Dias, S. L. P.; Gushikem, Y.; Kubota, L. T.; Quim. Nova 2006, 29, 208.

42. Rocha, R. F.; Rosatto, S. S.; Bruns, R. E.; Kubota, L. T.; J. Electroanal. Chem. 1997, 433, 73.

43. Dias, S. L. P.; Fujiwara, S. T.; Gushikem, Y.; Bruns, R. E.; J. Electroanal. Chem. 2002, 531, 141.

44. Ribeiro, E. S.; Dias, S. L. P.; Fujiwara, S. T.; Gushikem, Y.; Bruns, R. E.; J. App. Electrochem. 2003, 33, 1069. 
45. Pereira, A. U.; Kubota, L. T.; Quim. Nova 2004, 27, 725.

46. Porto, A. L. M.; Cassiola, F.; Dias, S. L. P.; Joekes, I.; Gushikem, Y.; Rodrigues, J. A. R.; Moran, P. J. S.; Manfio, G. P.; Marsaioli, A. J.; J. Mol. Catal. B: Enzym. 2002, 19-20, 327.

47. Simonet, J. In Organic Electrochemistry; Baizer, M. M.; Lund, H., eds.; $2^{\text {nd }}$ ed., Marcel Dekker Inc.: New York, 1983, p. 843.

48. Silva, L. R. D.; Gushikem, Y.; Kubota, L. T.; Coll. Surf. B: Biointerfaces 1996, 6, 309.

49. Silva, L. R. D.; Gushikem, Y.; Gonçalves, M. C.; Rodrigues Filho, U. P.; Castro, S. C.; J. App. Polym. Sci. 1995, 58, 1669.

50. Bard, A. J.; Faulner, L. R.; Electrochemical Methods: Fundamentals and Applications, John Wiley \& Sons: New York, 1980.

51. Huck, H.; Fresesenius Z. Anal. Chem. 1982, 313, 548.
52. Sampath, S.; Lev, O.; J. Electroanal. Chem. 1998, 446, 57.

53. Persson, B.; Gorton, L.; J. Electroanal. Chem. 1990, $292,115$.

54. Pessoa, C. A.; Gushikem, Y.; Kubota, L. T.; Gorton, L.; J. Electroanal. Chem. 1997, 431, 23.

55. Ribeiro, E. S.; Rosatto, S. S.; Gushikem, Y.; Kubota, L. T.; J. Sol. State Electrochem. 2003, 7, 665.

56. Santos, A. S.; Gorton, L.; Kubota, L. T.; Electrochim. Acta 2002, 47, 3351.

57. Malinauskas, A.; Ruzgas, T.; Gorton, L.; J. Coll. Interf. Sci. 2000, 224, 325.

Received: April 11, 2007

Web Release Date: November 16, 2007

FAPESP helped in meeting the publication costs of this article. 